\title{
Environmental Policy, Public Health and Human Rights: Assessing the Regional Regulation on Waste
}

\author{
Toar Neman Palilingan, Donna Okthalia Setiabudhi*, Toar K.R. Palilingan \\ Faculty Law, Sam Ratulangi University, Indonesia. \\ *Corresponding authorE-mail:donna_setiabudhi@yahoo.com
}

\begin{tabular}{l} 
ARTICLE INFO \\
\hline Keywords: \\
Environment; Legal Policy; \\
Public Health; Human \\
Rights \\
How to cite: \\
Palilingan, T.N., Setiabudhi, \\
D.O., E Palilingan, T.K.R. \\
(2018). "Environmental \\
Policy, Public Health and \\
Human Rights: Assessing \\
the Regional Regulation on \\
Waste," Hasanuddin Law \\
Review, 4(3): 339-347 \\
DOI: \\
10.20956/halrev.v4i3.1413
\end{tabular}

\begin{abstract}
Everyone has the right to a good and healthy environment as part of human rights. Hence, to actualize the right to a good and healthy environment, the community or everyone has the right to environmental information related to the role in environmental management. The research is a socio-juridical. The results show that the management of human environment in Manado is implemented through the establishment and implementation of local regulations. The issuance of local regulations related to environmental law enforcement are local regulations on Environmental Protection and Management; Domestic Wastewater Management; and Waste Management and Cleaning Service Fees. However, the three local regulations have not been implemented optimally. Even the local regulation on the Waste Management and Cleaning Service Fees provides regulations that are not in accordance with the needs of the community in waste management and not in accordance with the laws and regulations related to waste.
\end{abstract}

Copyright (C) 2018 HALREV. All rights reserved.

\section{Introduction}

A State has main responsibility and duty to the peoples to protect the entire Indonesian nation and promote the general welfare as a mandate of constitutional. Article $28 \mathrm{H}$ paragraph (1) of the 1945 Constitution expressly states that "everyone shall be entitled to be prosperous, reside, and obtain proper and sound environment and medical services" as constitutional rights. This implies that the right to a decent and clean life does not only refer to the physical environment, but more than that, it is an essence and existence of humans to be guaranteed to fulfill the rights of human life.

Nowadays, although many environmental protection measures can be seen at some cities, but a more systematic and sustainable approach to reducing the negative impacts 
of those activities and making the area more sustainable, is generally lacking. ${ }^{1}$ The municipal of Manado, North Sulawesi of Indonesia is a developing area with a number of problems related to the environment. One of them is about waste management. The right to the environment in national law has been regulated explicitly in Act No. 32 of 2009 concerning Environmental Protection and Management. In general, this provision presents how important the environmental component in supporting and fulfilling the rights of human life. The right to the environment is a right that cannot be reduced under any circumstances. In addition, no allows types of discrimination in respect of human rights.

The damage of environmental must be prevented through good management and preservation of environmental functions, because without this it would threaten the existence of human life and the future of the earth as a whole. These ecological inequalities have been factually occurring and have resulted in the occurrence of natural disasters which have a very bad impact on the community. One example is floods that have occurred several times in Manado. In 2000, extreme flooding occurred in the city of Manado with an inundation area reaching \pm 761 ha with the height of 2.5 meters. In 2006, floods again occurred in the city of Manado that causing losses of approximately 100 billion, 1.526 houses inundated, 139 houses severely damaged, 31 houses washed away and 40 houses slightly damaged. In 2007, floods in the city of Manado occurred despite not causing losses and large victims and recently a very large flood occurs again with a greater loss of 1.8 trillion and more victims. This flood occurred after continuous rain which caused four large rivers that crossed Manado to overflow while the water hit the city/district around the region. ${ }^{2}$

The problems above are only a small part of the problems that occur in Manado related to the environment whether it is the problem of waste, garbage, or community participation in environmental management. Thus, it is necessary to study the legal substance that already exists in the city of Manado and looking its relevance to environmental management efforts that can uphold the rights of the community to a healthy environment.

\section{Method}

The research is a socio-juridical. Method used is descriptive to describe the issue of research systematically, factually and accurately. The site of research is centered in Manado city, North Sulawesi of Indonesia, as location that several time experiencing natural disaster related to the condition of environment. To analyze the data in this research, we further analyze qualitatively. The analysis is conducted by using theory basis and analysis key to explain the phenomenon as focus of this research.

\section{Relation of Human Rights and Environmental Management}

The term environment and human environment is often used interchangeable in similar sense. Often the sense of environment with human environment can be given different restriction based on the perception and discipline of science. In this paper, the term environment or human environment is similar in broad sense. Therefore, theoretically a

\footnotetext{
1 Alshuwaikhat, H. M., \& Abubakar, I. (2008). An integrated approach to achieving campus sustainability: assessment of the current campus environmental management practices. Journal of cleaner production, 16(16), 1777-1785.

2 Source: $h t t p: / / i d . w i k i p e d i a . o r g / w i k i / B a n j i r \_M a n a d o \_2014$
} 
space that restrict the environment is not restrict its broad, because the definition of human environment in broad sense is also covering the space solar system. ${ }^{3}$

Normatively, Article 1 of Act No. 32 of 2009 explains human environment protection and management as a systematic and integrated effort to preserve the environmental function and prevent pollution and/or environmental damage which includes planning, utilization, control, maintenance, supervision and law enforcement. ${ }^{4}$

Imam Supardi ${ }^{5}$ stated that environmental management is an effort to conserve the environment from the influence of development impacts. Good environmental management can prevent environmental damage due to a development project. It is not maintaining the ecosystem by preventing development, because development is necessary to improve the quality of human life. So, what is important here is to build on the basis of environmental insights rather than building with economic alone.

Everyone has the right to a good and healthy environment as part of human rights. To actualize the right to a good and healthy environment, the community or everyone has the right to environmental information related to the role in environmental management. 6 This environmental information can be in the form of data, information or other relating to environmental management which according to its nature and purpose are open to the public, such as an environmental impact analysis.

In relation to the theory of accountability, Black's Law dictionary calls it the term liability and responsibility. ${ }^{7}$ Liability is a broad legal term which, among other things implies the meaning of a condition subject to factual obligations such as losses, threats, costs, expenses, conditions that create the task to implement the law immediately or in the future. In another part, the Dictionary also mentions the term responsibility, that things can be accounted for an obligation and include decisions, skills, and abilities and the obligation to be responsible for disputed laws.

In the dictionary of Fockema Andreae, 8 there are 2 (two) concepts of responsibility, namely aansprakelijk, it means responsible for, bound, accountable according to the law for mistakes or consequences of an act. Whereas verantwoordelijk is liable for compensation for damages incurred and for mistakes committed. After elaborating the theory of accountability, it can be concluded that the sense of accountability as a freedom to act to carry out the task charged, but ultimately cannot escape from the resultant of action freedom, in the form of prosecution to carry out what is required properly. This view is in line with the limitations of the Administration Encyclopedia that defines responsibility as the necessity of someone to do properly what has been required of him. ${ }^{9}$ Thus, the essence of responsibility is a balance between an authority and rights when government officials exercise the authority they carry out in violation of the rules resulting in neglect of community interests and rights.

Suhartio, R.B. (2001). Perlindungan Hak Dunia Ketiga atas Sumberdaya Alam. Yogyakarta: PT. Tiara Wacana, p. 32

4 This notion describes that environment protection and management as expected by Indonesia has broad coverage that will includes persuasive, preventive, curative, and repressive efforts.

5 Supardi, I. (2003). Lingkungan Hidup dan Kelestariannya. Bandung: Alumni, p. 171

Hardjasoemantri, K. (2001). Hukum Tata Lingkungan. Yogyakarta: Gajah Mada Press University. P. 93

Ridwan, H.R. (2006). Hukum Administrasi Negara. Jakarta: PT RajaGrafindo Persada, p. 335

Elgra, N.E. et al. (1983). Kamus Istilah Hukum Fockema Andreae Belanda-Indonesia. Jakarta: Bina Cipta. p. 607 and 608

9 Sutarto. (2007). Encyclopedia Administrasi. Jakarta, p. 291. 
In relation to environmental management in Indonesia, it appears that the role of the State is to provide protection for people' rights to a healthy environment. This role gives the State an obligation to make efforts both substantively through the establishment of legislation and practically through the implementation of environmental management which aims to give the community the right to a healthy environment as a right guaranteed by the constitution.

Obligation of the State to realize the right to a healthy environment is carried out both at the central and regional levels. By these conditions, the discourse of State' responsibility in the community' protection to the environmental damage becomes urgent to realize the implementation of government accountable to the people as a constitutional right.

\section{Local Regulation on Waste and Reality in Human Environment Management}

Rapid development in the city of Manado through physical development every time and every day is carried out for the benefit of the community. But in reality, it shows that the development has not fully supported the protection, management and preservation of the human environment. As an example of physical developments, such as the construction of shop houses, other public facilities such as hospitals built on the borders of rivers and shores. Hence, this physical development is not considering the natural conditions at the location but tends to damage. Dwelling in the riverbanks are increasingly seen even though the negative impacts are known, namely floods and decreasing river water quality as sources of clean water.

Basically, the human environmental management in the city of Manado has been implemented through the establishment of local regulations relating to the human environment such as local regulations on environmental protection and management, local regulations on waste as well as water management. These local regulations basically become a reference for the implementation of environmental management in the city of Manado. ${ }^{10}$ However, the effectiveness of environmental management certainly cannot be separated from the implementation of the local regulations.

Local regulations on the Human Environment Protection and Management and also Domestic Wastewater Management in Manado is still relatively new, so that the implementation of both local legislations still needs a longer time to be able to assess its effectiveness. As a preliminary assessment of the implementation of both local regulations can be viewed on the dissemination of relevant agencies regarding the presence of both local regulations and based on research conducted, socialization and counseling about both the local regulations have not been optimally practical and comprehensive. This can be seen in the questionnaire given to respondents to the local government, civil society and the private sector were mostly (averaged over 85\%) did not know about the local regulations on the Environment Protection and Management and regarding Domestic Wastewater Management.

In addition to the both local regulations above, the local regulation in the city of Manado relating to environmental management that deserve attention are the local regulation on waste management and cleaning service fees. The problem of waste is closely related to Act No. 18 of 2008 concerning Waste Management which regulates all aspects of management on the waste and as main rule of the waste regulations under it. In waste

10 Setiabudhi, D.O., Palilingan, T.N., and Kermite, J.A. (2018). Population Administration Policy: An Empirical and Juridical Examination, Brawijaya Law Journal 5 (2): 209-216. DOI: http://dx.doi.org/10.21776/ub.blj.2018.005.02.05 
management laws is also mentioned prohibition for anyone to enter the waste into the territory of the Republic of Indonesia, importing trash, mix waste with hazardous and toxic waste, manage waste caused pollution and/or destruction of the environment, taking out the trash is not on a place that has been provided, handling waste by open disposal at the final processing site and burning waste that is not in accordance with the technical requirements of waste management.

Previously, the enactment of Act No. 18 of 2008 and Act No. 32 of 2009, the government also issued Government Regulation No. 65 of 2005 concerning Guidelines for the Preparation and Application of Minimum Service Standards. In this regulation, it is stated that the Minimum Service Standard is a provision on the type and quality of basic services which is a region obligatory for every citizen to have a minimum.

In relation to the public services, Act No. 25 of 2009 concerning Public Services was issued. In this law, it is stated that public service is an activity or series of activities in the context of fulfilling service needs in accordance with the laws and regulations for every citizen and population of goods, services and/or administrative services provided by public service providers. Based on various provisions above, there is a responsibility of the local government towards waste management that is harmonized with norms, standards, procedures, and criteria for public service.

At the regional level, the government of Manado has also issued Local Regulation No. 7 of 2006 concerning Waste Management and Cleaning Service Fee as a legal instrument in Manado which is expected to support efforts to realize the city of Manado into a clean and healthy city as one of the embodiments of the role of local government in giving people the right to a healthy environment.

By the issuance of various regulations both at the central and regional levels relating to waste management, cleanliness, environment, and public services as stated above, it is still unable to overcome the problem of waste in the city of Manado. This is evident from the increasing problem of waste and even from year to year tends to increase. In addition, after the establishment of Local Regulation No. 7 of 2006, there were so many significant changes in legal instruments related to waste management so that policy measures were needed in anticipating waste problems in the city of Manado both in terms of and measures for solid waste management. Anticipating changes in various regulations, the Mayor of Manado issues Mayor Regulation No. 50 of 2017 concerning the Master Plan of Manado Waste Management System, but on a level of regulation, the position of Mayor regulation is still under the Local Regulation.

Waste management is the responsibility of the government, local government, community and business actors. Basically, it is the embodiment of Article 28 paragraph (1) of the 1945 Constitution of the Republic of Indonesia which gives the right to everyone to get a good and healthy environment and this has the consequence that the government is obliged to provide public services in waste management. In addition, waste management does not only require aspects of active participation and legal in the form of local regulations, but institutional, management, operational and financing aspects. These aspects in a waste management system is carried out in a comprehensive and integrated manner. 
To provide legal certainty, clarity of responsibilities and authority of local governments as well as the rights and obligations of the community and business actors required a legal basis that regulates comprehensively and integrated from upstream to downstream, so that the implementation of waste management can run proportionally, effectively and efficiently.

Local regulation on waste management consists of title, consideration, legal basis, torso, conclusion and explanation. As for local regulation No. 7 of 2006 needs to be reviewed as follows: 11

\subsection{Title of Local Regulation}

Local regulation No. 7 of 2006 has a title of Local Regulation on Waste Management and Cleaning Service Fees. This local regulation presents that the regulated content is about waste management and cleaning service fees. Arrangements regarding cleaning service fees need to be reviewed considering that currently the local regulation on retribution or fees must be regulated separately in the local regulation on retribution so that the title of the Local Regulation that needs to be included is the local regulation on waste management.

\subsection{Considering}

Consider in Local Regulation No. 7 of 2006 needs to be amended by state clearly the philosophical, sociological and juridical matters that underlie the issuance of this local regulation as follows:

a) Local Regulations on Waste Management are issued by taking into account the views of life, awareness, legal ideals which include the condition of spritual and Indonesian philosophy derived from Pancasila and the opening of the 1945 Constitution of the Republic of Indonesia.

b) Local Regulations on Waste Management are issued to meet the needs of the community in various aspects, especially aspects of community life.

c) Local Regulations on Waste Management are issued to overcome legal problems or fill legal void by considering the existing rules, which will be amended or will be revoked to ensure legal certainty and a sense of justice for the community.

\subsection{Legal Basis}

The legal basis for the issuance of the local regulation on consideration contains a legal basis as basis of the authority of the local government in establishing local regulations and contains laws and regulations that consider the issuance of local regulations on waste management. The legal basis in Local Regulation No. 7 of 2006 needs to be amended because most of the legal basis in the local regulation has been revoked and amended with the latest legislation, so that the legal basis that can be included in the Local Regulation on Waste Management namely:

a) Act No. 18 of 2008 on Waste Management

b) Act No. 36 of 2009 on Health

c) Act No. 32 of 2009 on Environmental Protection and Management

d) Act No. 12 of 2011 on the Issuance of Legislation

11 Setiabudi, D.O. (2016). Urgensi Pembentukan Peraturan Daerah tentang Pengelolaan Sampah di Kota Manado, Journal, Manado. 
e) Act No. 23 of 2014 on Local Government

f) Government Regulation No. 81 of 2012 on Household Waste Management and Household-like Waste

g) Regulation of Environment Minister No. 16 of 2011, and;

h) Regulation of Public Works Minister No. 3 of 2013 on the Implementation of Waste Infrastructure in the Handling of Household Waste and Household-like Waste.

\subsection{Content Material}

In the article on general provisions in local regulation No. 7 of 2006 needs to be adjusted especially on terms related to retribution because the regulation regarding retribution will be abolished in this regulation. Local Regulation No. 7 of 2006 does not contain the principles, objectives and scope so that in the amendment to this local regulation it is necessary to regulate the principles including principles of responsibility, preservation and sustainability, integration, justice, prudence, participatory, benefits, good governance and the principle of polluters pay. The next material that needs to be regulated is the purpose of waste management, namely to create a healthy and clean environment, to preserve environmental functions and maintain public health, to increase the participation of the community and business actors to actively reduce and/or handle waste that is environmentally sound, making waste as a resource that has economic value and realize effective and efficient waste service performance. The scope of the regulation that can be included is household waste, household-like waste.

a) Local Regulation No. 7 of 2006 does not emphasize the duties and authority in waste management so that need to be amended by including duties and authority in waste management. Local Regulation No. 7 of 2006 does not regulate waste management so that need to be amended, among others regarding waste reduction, waste handling, waste segregation, waste collection, waste transportation, waste management, final waste processing and regional landfill.

b) Local Regulation No. 7 of 2006 does not regulate licensing so it is necessary to regulate licensing related to recycling, transportation, processing, and final processing by setting the licensing period and its extension. Local Regulation No. 7 of 2006 still generally gives management authority to the Mayor. This needs to be amended by adjusting to Act No. 18 of 2008 that the management agency can includes NGOs, Regional Technical Implementing Unit, BLUD, Regional Apparatus and or Regional-Owned Corporation.

c) Local Regulation No. 7 of 2006 does not regulates Financing and Compensation so that further arrangements need to be made on this matter related to financing sources for waste management, the obligation to pay for waste management services for people who use or receive service benefits as well as regulating compensation that must be given to those affected waste handling and management activities related to the types of impacts that are given compensation, forms of compensation, and procedures for awarding compensation. Local Regulation No. 7 of 2006 does not regulates incentives for institutions that make waste reduction and/or processing related to the form of activities that receive incentives.

d) Local Regulation No. 7 of 2006 does not regulates the participation of the community so it needs to be regulated in this regard considering that the participation of the community is an important part of the effort to realize the goals of waste management including in this case the possibility for the community to 
submit complaints related to waste management. All provisions concerning sanctions in Local Regulation No. 7 of 2006 needs to be amended and adjusted to the articles of amendments in this regulation and adjust to the current laws and regulations.

As described above indicates that Local Regulation No. 7 of 2006 provides regulations that are not in accordance with the conditions and needs of the community in waste management and are not in accordance with the legislation related to waste, it is recommended to make amendment to the Local Regulation by making adjustments to the legislation established after the establishment of the Local Regulation and adjusting to the current conditions, interests and needs of the people of Manado.

Waste problem is a problem that encompasses people' lives from the lowest to the national level, but to be able to prevent and overcome waste problems, it is necessary to innovate which will be effective in supporting optimization of waste management in Manado.

Currently, an organizational and management aspect in waste management in Manado is a multi-disciplinary activity that relies on the principles of engineering and management concerning the economic, social, cultural, and physical conditions of the City, and paying attention to those served by the city community. The design and selection of organizational forms is in accordance with the government regulations that develop it, the pattern of applied operational systems, the working capacity of the system and the scope of work and duties that must be handled.

In Indonesia, the policies applied in managing municipal waste are formally directed by the Ministry of Public Works as a technical agency that fosters urban waste management in Indonesia and if viewed from the government level, the lowest level of government as executing is the level of sub-district while in reality, those who are closest to the community and most understand the conditions that exist in the community are at village level and the environment so that this needs to be one of the considerations in determining institutions that are authorized to carry out waste management.

Local Regulation No. 7 of 2006 stipulates that waste management is under the authority and responsibility of the Mayor. Waste management should be carried out by dividing the authority between the regulator and the operator, so that an integrated and sustainable management will be created. This can be done, among others by giving authority to the UPTD as a regulator and the private sector as an operator.

It shows that overall the implementation of local regulations relating to environmental management in the city of Manado has not run optimally. Currently, for the local regulation on Environmental Protection and Management and the Local Regulation on Domestic Wastewater Management has been issued but it has not been implemented optimally, even there are still many local government officials and the public and the private sector who are not aware of the existence of these two local regulations while for local regulations on waste management, this still has problems related to local regulations that are not in accordance with the new law and there are still many content materials that are not in accordance with the current condition. 


\section{Conclusion}

The management of human environment in Manado is implemented through the establishment and implementation of local regulations. The issuance of local regulations related to environmental law enforcement are local regulations on Environmental Protection and Management; Domestic Wastewater Management; and Waste Management and Cleaning Service Fees. However, the three local regulations have not been implemented optimally. Even the local regulation on the Waste Management and Cleaning Service Fees provides regulations that are not in accordance with the needs of the community in waste management and not in accordance with the laws and regulations related to waste.

It is recommended for the issuance of Local Regulations relating to the environment by harmonizing with higher legislation. In addition, adjustments are needed to the current conditions of the interests and needs while still containing local wisdoms as an integral part of the values that live in the midst of community.

\section{References}

Alshuwaikhat, H. M., \& Abubakar, I. (2008). An integrated approach to achieving campus sustainability: assessment of the current campus environmental management practices. Journal of cleaner production, 16(16), 1777-1785.

Elgra, N.E. et al. (1983). Kamus Istilah Hukum Fockema Andreae Belanda-Indonesia. Jakarta: Bina Cipta.

Hardjasoemantri, K. (2001). Hukum Tata Lingkungan. Yogyakarta: Gajah Mada Press University.

Ridwan, H.R. (2006). Hukum Administrasi Negara. Jakarta: PT RajaGrafindo Persada.

Setiabudhi, D.O., Palilingan, T.N., and Kermite, J.A. (2018). Population Administration Policy: An Empirical and Juridical Examination, Brawijaya Law Journal 5 (2): 209216. DOI: http://dx.doi.org/10.21776/ub.blj.2018.005.02.05

Setiabudi, D.O. (2016). Urgensi Pembentukan Peraturan Daerah tentang Pengelolaan Sampah di Kota Manado, Journal, Manado.

Suhartio, R.B. (2001). Perlindungan Hak Dunia Ketiga atas Sumberdaya Alam. Yogyakarta: PT. Tiara Wacana.

Supardi, I. (2003). Lingkungan Hidup dan Kelestariannya. Bandung: Alumni.

Sutarto. (2007). Encyclopedia Administrasi. Jakarta: Gunung Agung.

Wikipedia. Source: http://id.wikipedia.org/wiki/Banjir_Manado_2014 